\title{
Paediatric Reference Values for Urinary Catecholamine Metabolites Evaluated by High Performance Liquid Chromatography and Electrochemical Detection ${ }^{1}$ )
}

\author{
Nora Marchese, Silvana Canini, Laura Fabi and Luciano Famularo
}

$1^{\circ}$ Laboratorio di Analisi Chimico-Cliniche, Istituto Giannina Gaslini, Genova, Italy

\begin{abstract}
Summary: The majority of the published reference range data on catecholamines excretion by healthy children is incomplete and often contradictory (1). We assayed in the urines of 127 healthy children the values of the catecholamines (norepinephrine, epinephrine, dopamine) and their methylated metabolites (normetanephrine, metanephrine, 3-methoxytyramine) for the determination of paediatric reference ranges. Data were expressed as $\mu \mathrm{g} / 24 \mathrm{~h}, \mu \mathrm{mol} / 24 \mathrm{~h}$ and $\mathrm{mmol} / \mathrm{mol}$ creatinine. An isocratic HPLC procedure by ion-pair reversed phase chromatography on a $\mathrm{C} 18$ column, using a single mobile phase containing formic acid, acetonitrile, diethylamine and octane sulphonic acid (ion pairing agent), permitted the separate assay of the various fractions of total catecholamines. The relations between each biogenic amine and age were studied and reference values were determined as a function of age.
\end{abstract}

\section{Introduction}

Neural crest tumours such as neuroblastoma and ganglioneuroma are associated with an abnormal secretion of catecholamines in tissue and body fluids. Assays of urinary vanillylmandelic acid, homovanillic acid, and dopamine permit biochemical diagnosis of neuroblastoma in approximately $80 \%$ of patients (2).

Differential diagnosis of phaeochromocytoma, neuroblastoma and related diseases requires multiple investigations, among which the determination of the catecholamines and of their metabolites is of primary importance (3).

Catecholamines are compounds containing aliphatic amines attached to a benzene ring bearing two hydroxyl groups in 3,4 position (catechol). They are derivatives of the amino acid tyrosine. Catecholamines are extensively metabolized; only $2-10 \%$ are eliminated in urine, the major part in conjugated form, and less than $20 \%$ are eliminated as methylated metabolites (essentially conjugated): normetanephrine, metanephrine and 3-methoxytyramine. Norepinephrine is the main neurotransmitter of the autonomic nervous system, dopamine is both a precursor of norepinephrine and a neuromediator of the central nervous system. The adrenal medulla contains norepinephrine $\mathrm{N}$-methyltransferase, which converts norepinephrine into epinephrine. The catecholamine metabolic pathways are illustrated in figure 1.

\footnotetext{
$\left.{ }^{1}\right)$ Supported in part by the "Associazione Italiana per la Lotta al
} Neuroblastoma".
High-performance liquid chromatography with amperometric detector (HPLC-EC) methods allows the separate assay of various catecholamine fractions: norepinephrine, epinephrine, dopamine, normetanephrine, metanephrine, 3-methoxytyramine (4).

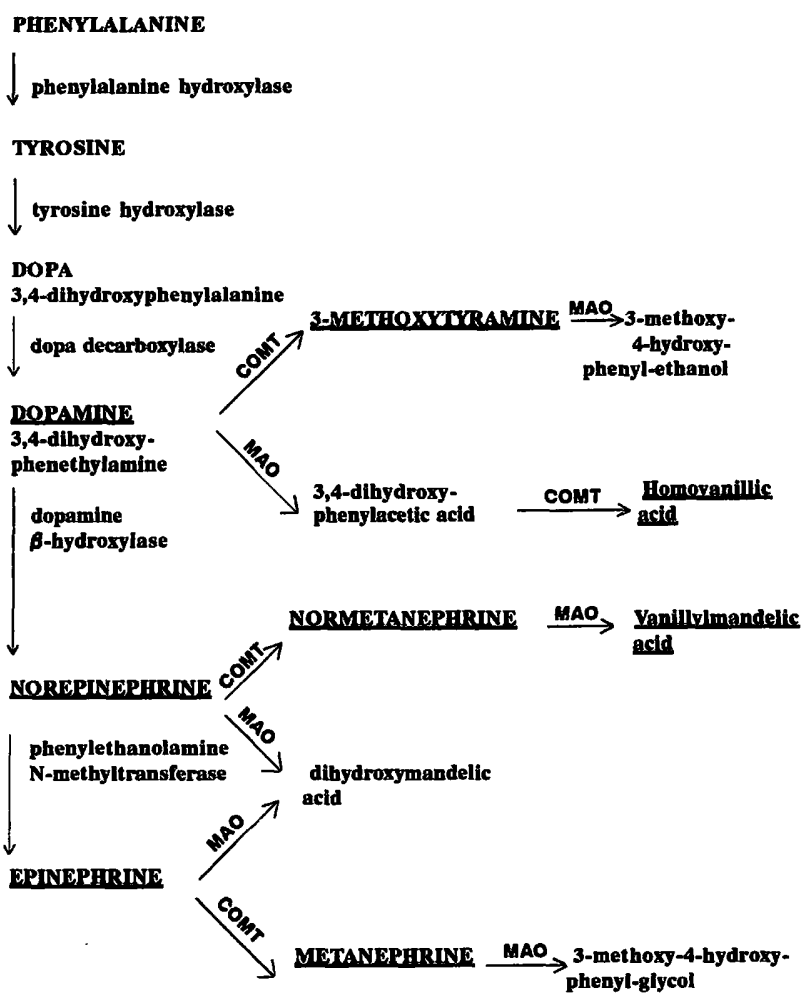

Fig. 1 Catecholamine pathways.

MAO: monoamine oxidase; COMT: catechol-O-methyl transferase [Modified from Candito M. et al. (3)]

The underlined compounds are those assayed in our laboratory. 


\section{Materials and Methods}

\section{Sample collection}

Twenty-four-hour urine specimens were collected in polyethylene boxes containing $4 \mathrm{ml}$ per litre of an acidic buffer mixture of $\mathrm{CH}_{3} \mathrm{COOH} 4 \mathrm{~mol} / 1 / \mathrm{NaOH} 4 \mathrm{~mol} / \mathrm{l}(4+1$, by vol. $)$ as preservative. The volume of the specimen was measured; an aliquot was stored at $-20^{\circ} \mathrm{C}$. Normal reference values were calculated on 127 healthy children aged 21 days to 14 years (mean: 50 months, median: 36 months): some of them were from the school and some were outside or inside patients without specific symptoms of hypertension. All the above-mentioned compounds were assayed in the urine of children before any treatment.

\section{Analytical methods}

Creatinine values were measured by the Jaffe method (5) on the Synchron CX 7 (Beckman Instruments, Inc. Brea, CA 926216209).

For the determination of total (free and conjugated) concentrations of catecholamines, the urine samples were hydrolyzed. To $1 \mathrm{ml}$ urine and $250 \mu \mathrm{l}$ of internal standard (dihydroxybenzylamine) $\mathrm{HCl}$ concentrated to $\mathrm{pH} 1$ was added and then heated to $100^{\circ} \mathrm{C}$ in a closed tube for 20 minutes (6). After hydrolysis, the $\mathrm{pH}$ of the mixture was adjusted to 6.5 with $2 \mathrm{~mol} / 1$ and $0.5 \mathrm{~mol} / \mathrm{l} \mathrm{NaOH}$ successively. The urine neutralised was purified by a cation exchange column of resin Amberlite CG 50 (Acros Organics, New Jersey, USA); the biogenic amines were eluted with $5 \mathrm{ml}$ of $0.1 \mathrm{~mol} / 1$ nitric acid. The eluate $(20-50 \mu \mathrm{l})$ was injected into the HPLC system $(4,6)$.

HPLC-EC was performed on a $125 \mathrm{~mm} \times 4 \mathrm{~mm}$ i. d. LichroCARTSuperspher 100 RP-18 (E. Merck, Darmstadt, Germany) column filled with $5 \mu \mathrm{m}$ particle size. A similar pre column (LiChrocart 44) was used.

The system was automated with an autosampler model ISS 100 (Perkin Elmer Corporation, Norwalk, USA). The results were processed by a computing integrator model LC100 (Perkin Elmer).

Mobile phase: Formic acid $(100 \mathrm{nmol} / \mathrm{l}) /$ citric acid $(1 \mathrm{mmol} / \mathrm{l}) / \mathrm{oc}-$ tane sulphonic acid $(0.4 \mathrm{mmol} / \mathrm{l}) /$ ethylenediaminotetraacetic acid (EDTA) $(0.1 \mathrm{nmol} / \mathrm{l})$ and $5 \%$ acetonitrile, diethylamine $(0.25 \%)$, $\mathrm{pH} 3.1$ with $\mathrm{KOH} 0.5 \mathrm{~mol} / \mathrm{l}$.

Flow rate: $0.7 \mathrm{ml} / \mathrm{min}$ isocratic

Detection: $750 \mathrm{mV}$ by model LC $4 \mathrm{C}$ electrochemical detector (BAS, Indiana, USA).

\section{Statistical methods}

The correlation among biogenic amines and between each catecholamine and age was investigated by non-parametric Spearman test.

When the population had a Gaussian distribution, reference limits were determined by a linear regression as a function of the childrens age.

If data distribution was not normal, the different groups were compared by Kruskal-Wallis test.

\section{Results}

\section{Analytical results}

Intra- and inter-assay imprecisions were determined from analysis of Ortho and Biorad normal and pathological control urines and from a normal urine.

Intra-assay coefficients of variation (CV) were: $10.5 \%$ for norepinephrine, $9.5 \%$ for epinephrine, $6 \%$ for dopamine, $7 \%$ for metanephrine, $8.5 \%$ for normetanephrine and $5 \%$ for 3-methoxytyramine. Inter-assay CVs were: $13.5 \%$ for norepinephrine, $10.5 \%$ for epinephrine, $5 \%$ for dopamine and 3-methoxytyramine, $6 \%$ for metanephrine and normetanephrine.

Recoveries were different: $90 \%$ for norepinephrine, $89 \%$ for epinephrine, metanephrine and normetanephrine, $102 \%$ for dopamine and $92 \%$ for 3-methoxytyramine. We had a good linearity from $50 \mathrm{pg}$ to $100 \mathrm{ng}$ of norepinephrine with less than $5 \%$ deviation from the fit line.

The determination of the lower detection limits of the components was based on the linear dilution of their standards. The detection limits were $9 \mathrm{nmol} / 1$ for norepinephrine, $11.5 \mathrm{nmol} / 1$ for epinephrine, $11.9 \mathrm{nmol} / 1$ for dopamine, $11 \mathrm{nmol} / 1$ for metanephrine and $11.3 \mathrm{nmol} / 1$ for normetanephrine and $7.1 \mathrm{nmol} / 1$ for 3-methoxytyramine, using $50 \mu \mathrm{l}$ injection volume of a standard solution and of an Ortho normal control urine appropriately diluted.

\section{Statistical results}

Different catecholamine metabolites were poorly correlated among themselves: this event demonstrated a different information provided by each analyte.

All biogenic amine levels, except normetanephrine, were strictly related to age $(r=$ about 0.7$)$. Therefore it was necessary to express reference values in relation with patient age.

If the values were calculated as $\mu \mathrm{g} / 24 \mathrm{~h}$ or $\mu \mathrm{mol} / 24 \mathrm{~h}$, they appeared with no Gaussian distribution even after logarithmic transformation. On the contrary these values showed a normal distribution if they were expressed as $\mathrm{mmol} / \mathrm{mol}$ creatinine and transformed in natural logarithm.

Opportune age intervals that appeared significantly different were determined for epinephrine, norepinephrine, dopamine, normetanephrine, metanephrine, and 3-methoxytyramine levels calculated as $\mu \mathrm{g} / 24 \mathrm{~h}$ and $\mu \mathrm{mol} /$ $24 \mathrm{~h}$. These intervals are graphically illustrated in figure 2 .

Table 1 reports upper reference limits and their confidence intervals.

The relations between childrens age and the different catecholamine metabolites expressed as $\mathrm{mmol} / \mathrm{mol}$ creatinine are reported in figure 3 as linear regressions. Their upper reference limits are also graphically illustrated in figure 3.

\section{Discussion}

The analytical method appeared easy and reproducible.

These reference ranges were established in agreement with International Federation Clinical Chemistry (IFCC) 

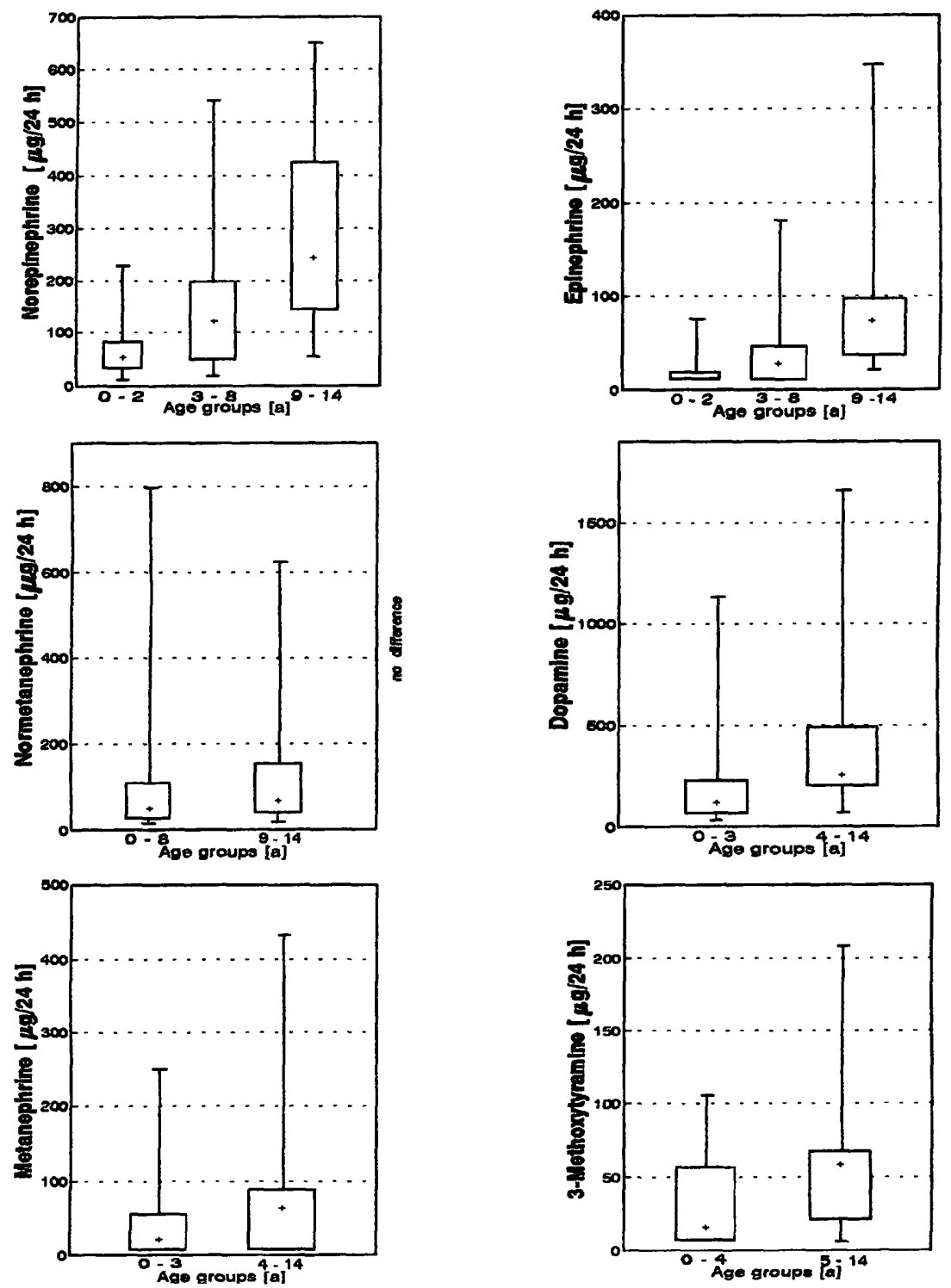

Fig. 2 Differences among distributions.

Tab. 1 Reference limits of chatecholamine urinary metabolites.

\begin{tabular}{|c|c|c|c|c|c|}
\hline & \multirow{2}{*}{$\begin{array}{l}\text { Age groups } \\
\text { (a) }\end{array}$} & \multicolumn{2}{|l|}{ Catecholamine } & \multicolumn{2}{|l|}{ Catecholamine } \\
\hline & & $\begin{array}{l}\text { Concentration } \\
(\mu \mathrm{g} / 24 \mathrm{~h})\end{array}$ & $\begin{array}{l}\text { Confidence } \\
\text { intervals } \\
(\mu \mathrm{g} / 24 \mathrm{~h})\end{array}$ & $\begin{array}{l}\text { Concentration } \\
(\mu \mathrm{mol} / 24 \mathrm{~h})\end{array}$ & $\begin{array}{l}\text { Confidence } \\
\text { intervals } \\
(\mu \mathrm{mol} / 24 \mathrm{~h})\end{array}$ \\
\hline Norepinephrine & $\begin{array}{l}0-2 \\
3-8 \\
9-14\end{array}$ & $\begin{array}{l}<274 \\
<590 \\
<680\end{array}$ & $\begin{array}{l}247-301 \\
579-601 \\
519-841\end{array}$ & $\begin{array}{l}<1.62 \\
<3.50 \\
<4.02\end{array}$ & $\begin{array}{l}1.46-1.78 \\
3.42-3.55 \\
3.07-4.97\end{array}$ \\
\hline Epinephrine & $\begin{array}{l}0-2 \\
3-8 \\
9-14\end{array}$ & $\begin{array}{l}<38 \\
<150 \\
<360\end{array}$ & $\begin{array}{r}35-41 \\
139-161 \\
291-428\end{array}$ & $\begin{array}{l}<0.21 \\
<0.82 \\
<1.97\end{array}$ & $\begin{array}{l}0.19-0.22 \\
0.76-0.88 \\
1.59-2.34\end{array}$ \\
\hline Normetanephrine & $0-14$ & $<827$ & $326-878$ & $<4.52$ & $1.78-4.79$ \\
\hline Dopamine & $\begin{array}{l}0-3 \\
4-14\end{array}$ & $\begin{array}{l}<1300 \\
<1876\end{array}$ & $\begin{array}{l}1240-1360 \\
1663-1989\end{array}$ & $\begin{array}{r}<8.49 \\
<12.25\end{array}$ & $\begin{array}{r}8.10-8.88 \\
10.89-12.98\end{array}$ \\
\hline Metanephrine & $\begin{array}{l}0-3 \\
4-14\end{array}$ & $\begin{array}{l}<254 \\
<461\end{array}$ & $\begin{array}{l}238-270 \\
433-489\end{array}$ & $\begin{array}{l}<1.29 \\
<2.34\end{array}$ & $\begin{array}{l}1.21-1.37 \\
2.19-2.48\end{array}$ \\
\hline 3-Methoxytyramine & $\begin{array}{l}0-4 \\
5-14\end{array}$ & $\begin{array}{l}<103 \\
<210\end{array}$ & $\begin{array}{r}94-112 \\
192-228\end{array}$ & $\begin{array}{l}<0.62 \\
<1.26\end{array}$ & $\begin{array}{l}0.56-0.67 \\
1.15-1.36\end{array}$ \\
\hline
\end{tabular}



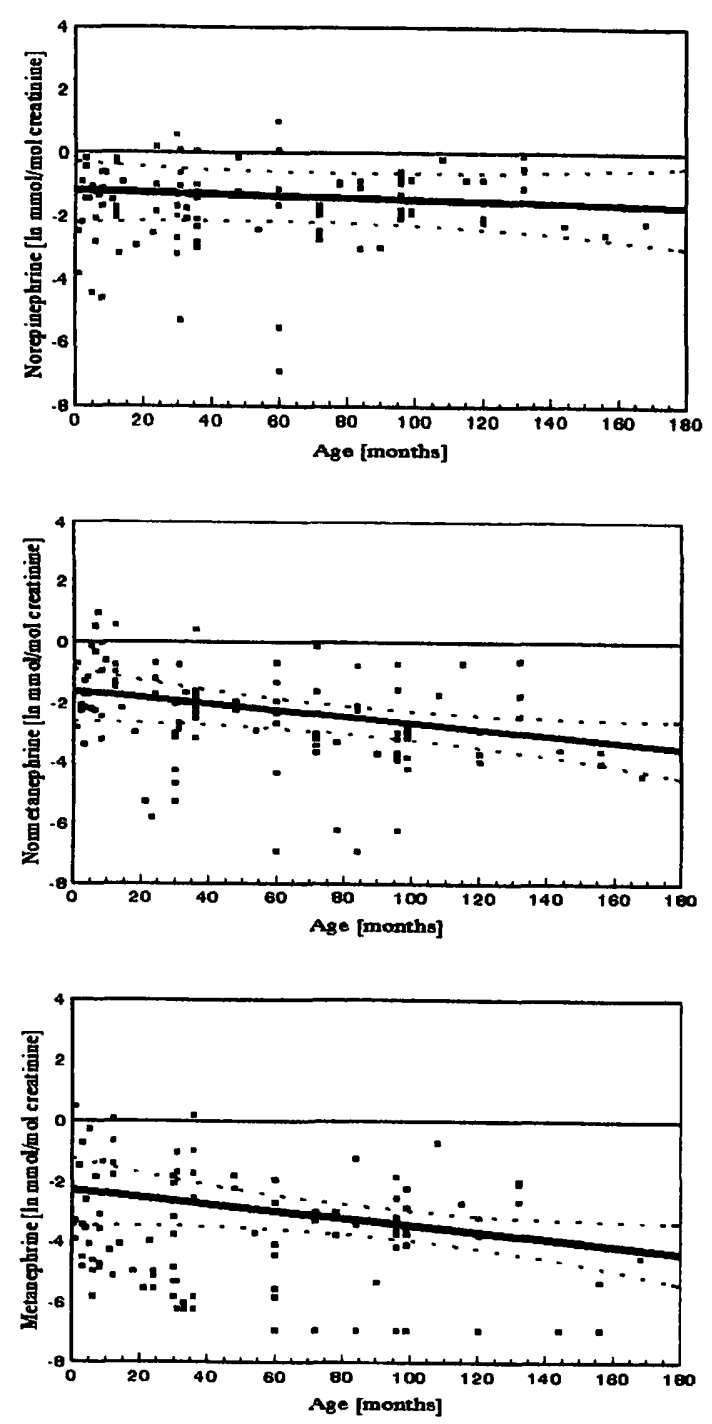

Fig. 3 Linear regressions.

In Norepinephrine $=-1.35-1.34 \times$ age (months) ln Epinephrine $\quad=-3.28-0.00007 \times$ age (months) ln Normetanephrine $=-1.36-1.52 \times$ age (months)

recommendations (7) and the data were described with an adequate graphic, preceded and complemented by a formal statistical analysis (8). We carefully selected local healthy children among our population.

Our reference values, with the exception of 3-methoxytyramine, are higher than those reported in the literature $(1,3)$; the increase of catecholamine excretion with age was already reported (9).

Many factors influence the large variation in published paediatric reference ranges for urine metabolites of catecholamines (1). There is no uniformity in the units reported from different laboratories. Data were expressed as $\mathrm{mmol} / \mathrm{mol}$ creatinine, $\mathrm{mmol} /$ day or $\mathrm{mmol} / \mathrm{kg}$ body weight with no possibility of comparing results $(10-12)$.

We chose to evaluate the total catecholamines (free and conjugated) with a published method (6) improving only
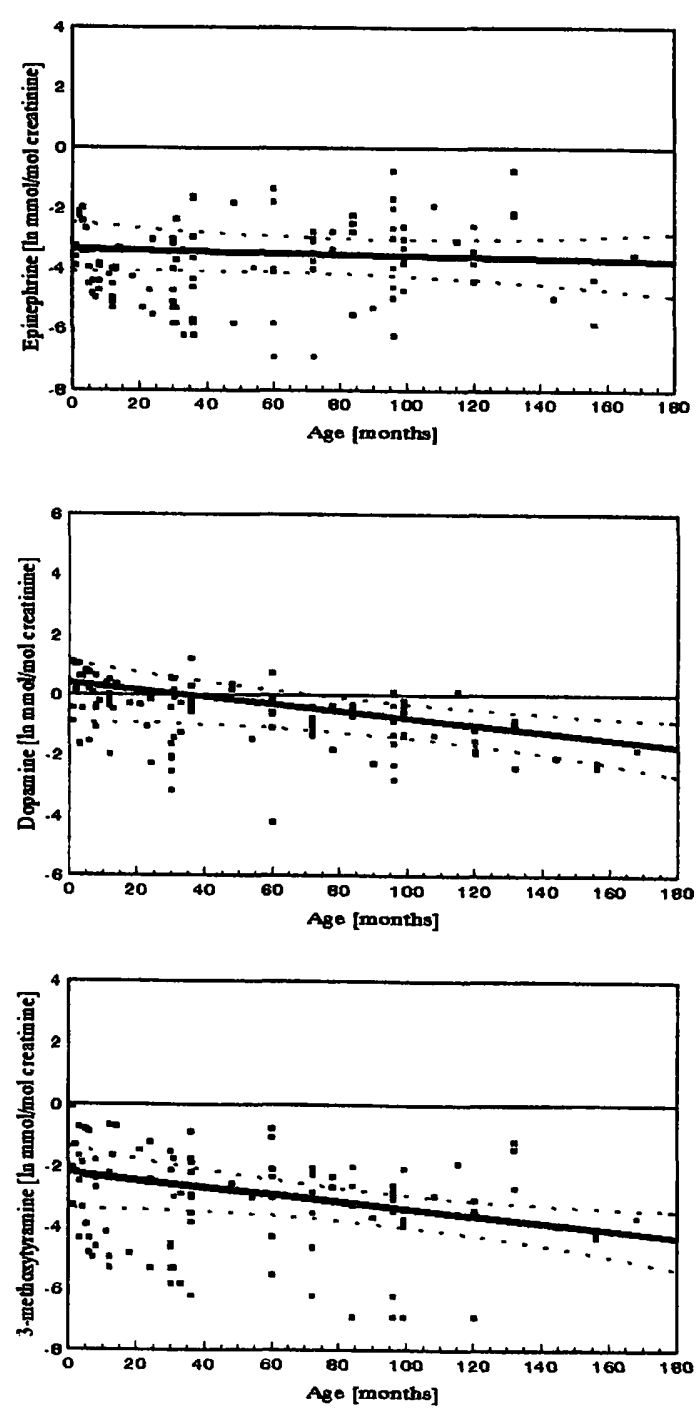
$\begin{array}{llll}\ln \text { Dopamine } & =-0.0051-0.001 \times \text { age (months) } \\ \text { ln Metanephrine } & =-2.71-0.012 \times \text { age (months) } \\ \ln \text { 3-Methoxytyramine } & =-2.23-0.0011 \times \text { age (months) }\end{array}$

the detection of these compounds with the use of an amperometric detector (4).

We assayed the total catecholamines because this way the information on the metabolism is more complete and the data give better information about the lowest variation of the excretion of the tumour (3). We had a good correspondence with the clinical findings of the patients affected by neuroblastoma and also of the children with hypertension.

The levels related with the creatinine excretion must be evaluated carefully because in the literature (13) a lot of articles describe the possible interference from diet (ingestion of meat) $(14)$, drugs $(15,16)$, analytical variation $(5-7 \%)$ and intra-personal fluctuation for younger children (13). All borderline values should be repeated routinely. 


\section{Conclusions}

Quantification of total urinary catecholamines is a reliable means of diagnosis and monitoring of neuroblastoma in children. None of these tests are $100 \%$ sensitive or specific in tumour detection and all metabolites should be measured. Catecholamine assays on serial urine samples of previously diagnosed patients proved to be helpful as prognostic markers, to identify relapse and response to chemotherapy.

\section{References}

1. Fitzgibbon MC, Tormey WP. Paediatric reference ranges for urinary catecholamines/metabolites and their relevance in neuroblastoma diagnosis [review article]. Ann Clin Biochem 1994; 31:1-11.

2. Lamedica G, Marchese N, Garaventa A, Canini S, Boni L, Parodi E, et al. Parametri biochimici per la diagnosi e la prognosi del neuroblastoma. Giorn It Chim Clin 1989; 14 (N.4):275-87.

3. Candito M, Thyss A, Albertini M, Deville A, Politano S, Mariani R, Chambon P. Methylated catecholanines metabolites for diagnosis of neuroblastoma. Med Ped Oncol 1992; 20:21520.

4. Di Bussolo JM, Gant JR, Kerber D. Instrumental considerations in catecholamines analysis using liquid chromatography with electrochemical detection. Chromatogr Newslett 1983; 11-1:27-9.

5. Jaffe MZ. Ueber den Niederschlag, welchen Pikrinsäure in normalem Harn erzeugt und über eine neue Reaction des Kreatinins. Physiol Chem 1886; 10:391-400.

6. Abeling NG, van Gennip AH, Overmars H, Voute PA. Simultaneous determination of catecholamines and metanephrines in urine by HPLC with fluorimetric detection. Clin Chim Acta 1984; 137:211-26.

7. Solberg HE. Approved recommendations on the theory of reference values. Part 5. Statistical treatment of collected reference values. Determination of reference limits. Clin Chim Acta 1987; 170:S13-32; J Clin Chem Clin Biochem 1987; 25:645-56.

8. Altman DG, Gore SM, Gardner MJ, Pocock SJ. Statistical guidelines for contributors to medical journals. Ann Clin Biochem 1992; 29:1-8.

9. Parra A, Ramirez del Angel A, Cervantes C, Sanchez M. Urinary excretion of catecholamines in healthy subjects in relation to body growth. Acta Endocrinol 1980; 94:546-51.
In our opinion it is necessary to increase standardisation of these methods and values by using automated procedures and on-line sample preparation: variation between-day and sample clean-up should be improved. This way published reference ranges become more widely applicable.

10. Henderson MJ, Heney D, McGinlay JM, Lewis I, Bailey C. Measurement of dopamine, HVA and HMMA in untimed urine samples; establishment of age related reference range data in children. Ann Clin Biochem 1992; 29:162-7.

11. Fitzgibbon MC, FitzGerald RJ, Tormey WP, O'Meara A, Kenny D. Reference values for urinary HMMA, HVA, noradrenaline, adrenaline and dopamine excretion in children using random urine samples and HPLC with electrochemical detection. Ann Clin Biochem 1992; 29:400-4.

12. Rosano TG. Liquid-chromatographic evaluation of age related changes in the urinary excretion of free catecholamines in paediatric patients. Clin Chem 1984; 30:301-3.

13. O'Meara A, Tormey W, FitzGerald RJ, Fitzgibbon M, Kenny D. Interpretation of random urinary catecholamines and their metabolites in neuroblastoma. Acta Paediatr 1994; 83:88-92.

14. Jacobsen FK, Christensen CK, Mogensen CE, Heilskov SC. Evaluation of kidney function after meals. Lancet 1980; i:319.

15. Payne RB. Creatinine clearance: a redundant clinical investigation. Ann Clin Biochem 1986; 23:243-50.

16. Van Acker BAC, Koomen GCM, Koopman MG, de Waart DR, Arisz L. Creatinine clearance during cimetidine administration for the measurement of glomerular filtration rate. Lancet $1992 ; 25: 492-3$.

Received January 29/April 25, 1997

Corresponding author: Dr. Nora Marchese, $1^{\circ}$ Laboratorio di Analisi Chimico-Cliniche, Istituto G. Gaslini, Largo G. Gaslini 5, I-16147 Genova, Italy 
